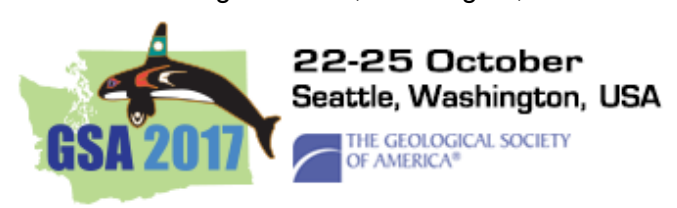

\title{
314-7: CHARACTERIZATION OF FRACTURE CHANGES UNDER HIGH PCO2: X-RAY COMPUTED MICROTOMOGRAPHY (XCMT) AND SEM IMAGES (Invited Presentation)
}

\author{
Wednesday, 25 October 2017 \\ 10:05 AM - 10:25 AM \\ P The Conference Center - Skagit 2
}

\section{Introduction}

The Hontomín reservoir formation for $\mathrm{CO}_{2}$ geological storage, located in Spain, is a deep saline aquifer that is mainly composed of limestone ( $80-85 \%)$ at the bottom and clast-poor sandstone (15-20\%) at the top. It has an upper impermeable seal made up of marls that should prevent escape of $\mathrm{CO}_{2}$ to the surface. The two reservoir rocks are fractured and the water formation is sulfate-rich and in equilibrium with calcite, dolomite and gypsum. As a result of the $\mathrm{CO}_{2}$ dissolution into the resident saline solution, mineral dissolution and precipitation processes will occur in the fractures. This phenomenon can imply changes in the geometry of the fractures and can alter their hydraulic and transport properties.

\section{Material and methods}

Flow-through percolation experiments were performed using artificially fractured limestone, sandstone and marl cores and injecting a $\mathrm{CO}_{2}$-rich sulfate solution under a constant volumetric flow rate at different $\mathrm{pCO}_{2}$ and $\mathrm{T}=60^{\circ} \mathrm{C}$.

$\mathrm{X}$-ray computed microtomography (XCMT) was used to characterize and localize changes in the fracture volume induced by dissolution and precipitation reactions. After the reacted samples were scanned, SEM images of the cores that were flooded with epoxy were taken to further analysis. The reacted cores were sectioned along a plane perpendicular to the fracture and parallel to the flow.

\section{Results and discussion}

Given the very small permeability $\left(\mathrm{k}<10^{-18} \mathrm{~m}^{2}\right)$ of the reservoir rocks the acidic $\mathrm{CO}_{2}$-rich water can only circulate through fractures. Under supercritical $\mathrm{CO}_{2}$ conditions and in $\mathrm{SO}_{4}$-rich waters, the changes in the open fracture volume are mainly due to dissolution of calcite and precipitation of gypsum. The variation in flow rate leads to formation of diverse dissolution patterns (e.g. wormholes), which takes place along the fracture.

As in the case of the reservoir rocks, the acidic $\mathrm{CO}_{2}$-rich water can only circulate through fractures in the marl rocks of the seal. Under supercritical $\mathrm{CO}_{2}$ conditions and in $\mathrm{SO}_{4}$-rich waters, the changes in the open fracture volume are due to dissolution of calcite and Mg-silicates and precipitation of gypsum and kaolinite. An altered skeleton-like zone (mainly made up of unreacted clays) forms along the fracture walls. Fracture permeability decreases under slow flow rates because precipitated gypsum seals the fracture.

\section{Authors}

\section{Jordi Cama}

Institute of Environmental

Assessment and Water

Research, CSIC

\section{Gabriela Davila}

University of Illinois Urbana Champaign
Maria Garcia-Rios

CNRS

Josep M. Soler

Institute of Environmental

Assessment and Water

Research, CSIC 
Final Paper Number 314-7

View Related Events

Day: Wednesday, 25 October 2017

Geological Society of America Abstracts with Programs. Vol. 49, No. 6 doi: 10.1130/abs/2017AM-300014

(c) Copyright 2017 The Geological Society of America (GSA), all rights reserved. 